\title{
Piloting a partially self-financed mode of human immunodeficiency virus pre-exposure prophylaxis delivery for men who have sex with men in Hong Kong
}

\author{
SS Lee, TH Kwan, NS Wong, Krystal CK Lee, Denise PC Chan, Teddy TN Lam, Grace CY Lui *
}

\section{A B S T R A C T}

Introduction: Pre-exposure prophylaxis (PrEP) with tenofovir disoproxil fumarate (TDF) $300 \mathrm{mg} /$ emtricitabine (FTC) $200 \mathrm{mg}$ is a proven strategy for preventing human immunodeficiency virus (HIV) transmission in men who have sex with men (MSM). This study aimed to test the feasibility and acceptability of PrEP delivered at a pilot clinic for MSM in Hong Kong, where PrEP service is currently unavailable.

Methods: Partially self-financed PrEP was provided to HIV-negative adult MSM with high behavioural risk of HIV transmission after excluding hepatitis $B$ infection and renal insufficiency. Participants received daily TDF/FTC for 30 weeks at $13.3 \%$ of the drug cost. Adherence and behaviours were monitored through questionnaires while creatinine and HIV/ STI (sexually transmitted infection) incidence were monitored with point-of-care and laboratory tests. Preference for continuing with PrEP was evaluated at the end of the prescription period.

Results: Seventy-onePrEP-naïveMSMwereincluded in the study, of whom $57(80 \%)$ were retained at the end of 28 weeks. Satisfactory adherence and selflimiting adverse events were reported, while none of the participants contracted HIV. Risk compensation was observed, with an STI incidence of 3.17 per 100
This article was published on 9 Oct 2019 at www.hkmj.org. majority (89\%) indicated interest in continuing with PrEP. Preference for PrEP was associated with age $\geq 28$ years and peer influence $(P=0.04)$, while stigma was a concern. Price was a deterrent to self-financed PrEP, and only half (51\%) considered a monthly cost of $\leq \mathrm{HK} \$ 500$ (US\$1=HK\$7.8) as reasonable.

Conclusions: A partially self-financed mode of PrEP delivery is feasible with good retention in MSM in Hong Kong.

\begin{tabular}{l} 
Hong Kong Med J 2019;25:382-91 \\
\hline https://doi.org/10.12809/hkmj198030 \\
${ }^{1}$ SS Lee, MD, FRCP \\
${ }^{2}$ TH Kwan, BSc \\
${ }^{1}$ NS Wong, PhD \\
1,3 KCK Lee, MB, BS, FHKAM (Community Medicine) \\
${ }^{1}$ DPC Chan, PhD \\
${ }^{4}$ TTN Lam, PharmD, PhD \\
1,5 GCY Lui *, MB, ChB, FRCP \\
${ }^{1}$ Stanley Ho Centre for Emerging Infectious Diseases, The Chinese \\
University of Hong Kong, Shatin, Hong Kong \\
${ }^{2}$ Jockey Club School of Public Health and Primary Care, The Chinese \\
University of Hong Kong, Shatin, Hong Kong \\
${ }^{3}$ Department of Psychiatry, Queen Mary Hospital, Pokfulam, Hong Kong \\
${ }^{4}$ School of Pharmacy, The Chinese University of Hong Kong, Shatin, \\
Hong Kong \\
${ }^{5}$ Department of Medicine and Therapeutics, The Chinese University of \\
Hong Kong, Shatin, Hong Kong \\
* Corresponding author: gracelui@ @cuhk.edu.hk
\end{tabular}

New knowledge added by this study

- A workable model for delivering affordable pre-exposure prophylaxis (PrEP) to men who have sex with men (MSM) at high risk of human immunodeficiency virus (HIV) infection in Hong Kong is important.

- Risk compensation as reflected by diagnosis of sexually transmitted infections (STIs) following PrEP is a concern in a proportion of MSM.

- Adverse events from the use of tenofovir disoproxil fumarate $300 \mathrm{mg}$ and emtricitabine $200 \mathrm{mg}$ for PrEP are not uncommon though normally self-limiting, but cessation may be required in a small proportion of PrEP users.

Implications for clinical practice or policy

Partially self-financed daily PrEP administered in conjunction with STI/HIV monitoring is operationally feasible and acceptable to MSM in Hong Kong, where PrEP is currently otherwise unavailable as a service.

\section{Introduction}

Pre-exposure prophylaxis (PrEP) with tenofovir disoproxil fumarate (TDF) $300 \mathrm{mg} /$ emtricitabine (FTC) $200 \mathrm{mg}$ is a key strategy for protecting people at high risk of human immunodeficiency virus (HIV) transmission. The effectiveness of PrEP for HIV prevention has been demonstrated in large-scale national studies ${ }^{1-3}$ and extensively reviewed in the literature. ${ }^{4}$ Mathematical modelling parameterised by data from the Netherlands concluded that PrEP for men who have sex with men (MSM) is cost-effective in the context of a stable HIV 
epidemic. ${ }^{5}$ Following approval of the Food and Drug Administration in the US, PrEP guidelines have been promulgated by the World Health Organization, ${ }^{6}$ the Centers for Disease Control and Prevention,? and the European AIDS Clinical Society. ${ }^{8}$ Despite promotions and advocacies at different levels, uptake of PrEP has remained low internationally, with wide disparities across countries. Of note, Asia has been reported to account for fewer than $5 \%$ of all PrEP initiations recorded worldwide. ${ }^{9}$ Notably, cost remains an important deterrent to its introduction in most cities/countries where generic TDF/FTC cannot be prescribed legally, and Hong Kong is no exception. Elsewhere, different service models for PrEP delivery have been developed, ${ }^{10}$ but there exists a "purview paradox" causing obstructions in societal implementation. ${ }^{11}$

In Hong Kong, PrEP is currently unavailable as an HIV prevention service, where MSM have continued to account for a high proportion of newly reported HIV infections (67\% in 2017; www.aids.gov. hk). A study was conceptualised to test the feasibility and acceptability of PrEP delivery by piloting a designated clinic to deliver lower-cost TDF/FTC to MSM at high risk of HIV transmission. The results of this study are expected to serve as a useful reference for the future development of sustainable PrEP programmes in Hong Kong.

\section{Methods}

\section{Pre-exposure prophylaxis clinic}

A research clinic was set up at Prince of Wales Hospital, the teaching hospital of The Chinese University of Hong Kong. In collaboration with HIV services and community-based organisations, eligible HIV-negative MSM were referred or selfreferred to join the study. A bilingual (Chinese and English) website was set up to provide information about PrEP, with linkages to eligibility screening and behavioural and adherence surveys through the online system.

\section{Participant recruitment}

Participants were MSM aged $\geq 18$ years who were normally resident in Hong Kong and could communicate in written and spoken English or Chinese. Potential participants who had not previously used PrEP were targeted. The main inclusion criteria were: firstly, history of unprotected anal sex in the preceding 6 months; and secondly, negative HIV antibody test result within the last 3 months; plus at least one of the following in the past 6 months: (a) diagnosis of sexually transmitted infection [STI], (b) sex partner(s) with positive or unknown HIV status, (c) history of recreational drug use during sex, ie, "chem-sex"; and/or (d) multiple sex partners. The exclusion criteria were: (a) having

\section{以部份自費模式在香港設立為男男性接觸者提供 愛滋病事前預防用藥試點}

李瑞山、關子浩、王艾斯、李芷琪、陳珮琮、林泰寧、雷頌恩

引言：服用TDF $300 \mathrm{mg} /$ FTC $200 \mathrm{mg}$ 作為事前預防用藥是一種經證 實的策略，可以預防愛滋病病毒在男男性接觸者之間傳播。目前香港 尚無此等服務, 本研究旨在設立試點診所測試事前預防用藥的可行性 和可接受性。

方法：研究針對具高風險行為而沒受愛滋病病毒感染的成年男男性接 觸者, 在排除乙型肝炎感染和腎功能不全後, 為他們提供需部分自費 的事前預防用藥。參與者一連30週每天服用TDF / FTC, 並付藥費的 $13.3 \%$ 。參與者需填答問卷以監察用藥依從性和行為風險, 並以快速 測試和實驗室測試檢測腎功能、愛滋病病毒和性病感染發生率。在處 方期結束時評估參與者對繼續使用事前預防用藥的傾向。

結果：71名從未服用事前預防用藥的男男性接觸者被納入研究, 其中 57 人 $(80 \%)$ 持續用藥 28 週。參與者的依從性令人滿意, 對藥物只產 生自限性不良反應, 沒有參與者感染愛滋病病毒。觀察期間出現風險 補償現象, 性病發病率為每 100 人年 3.17 。在處方期結束時, 大多數 人 $(89 \%)$ 表示有興趣繼續事前預防用藥。對事前預防用藥的偏好與 年齡28歲或以上和同伴影響相關（ $\mathrm{P}=0.04 ）$, 而感覺污名化則是一個 擔憂。藥物價格是自費模式的一種威懾, 只有一半 ( $51 \%$ ) 認為每月 低於 500 港元 $(1$ 美元 $=7.8$ 港元 $)$ 的費用是合理。

結論：以部分自費模式推行事前預防用藥是可行的, 得到香港的男男 性接觸者接受並持續使用

any form of mental illnesses; (b) inability or refusal to give consent; (c) incarceration; (d) known hepatitis $B$ virus infection; and (e) known renal insufficiency with creatinine clearance $<60 \mathrm{~mL} / \mathrm{min} / 1.73 \mathrm{~m}^{2}$.

\section{Pre-exposure prophylaxis regimen and monitoring}

Participants completed a pre-assessment to confirm their eligibility for inclusion in the study. A 2-week course of daily TDF/FTC was given free at the first visit to evaluate tolerance before the participant was asked to provide partial payment by instalment, covering a total prescription period of 30 weeks. The prescription was partially self-financed, as each person was required to pay HK\$1316(US\$1=HK\$7.8) 4 times for four consecutive prescription periods. As an incentive, the same payment entitled the participant to receive an increasing duration of medication. At week 28, a 2-week supply of medication was given free. The total cost was equivalent to $13.3 \%$ of the market price of patented TDF/FTC, or HK\$702 per month, in Hong Kong.

Three forms of monitoring were implemented: (a) questionnaires for periodic data collection on HIV risk behaviours, adverse reactions to antiretrovirals, and adherence to daily self-administered PrEP by tablet PC, at each consultation; (b) point-of-care and laboratory tests: fourth-generation HIV antibody/ antigen tests; plasma creatinine and estimated 
glomerular filtration rate; STI: syphilis serology, and urine tests for Neisseria gonorrhoeae and Chlamydia trachomatis by nucleic acid amplification test (NAAT); and (c) online diary for tracking daily intake of TDF/FTC and sexual activities. Finger prick was used for monitoring HIV, creatinine, and syphilis serology at selected time-points. Archived blood samples collected at baseline and week 28 were tested for hepatitis $C$ virus antibody. A weekly email reminder was sent to participants requesting completion of the online diary.

\section{Analyses}

Complete case analyses were performed addressing: (a) acceptability/feasibility: characteristics of participants; proportion of MSM interested in continuing with PrEP following the study; retention in the programme; (b) outcome evaluation: drug adherence; coverage of unprotected sex; adverse reactions; detection of STIs at baseline; subsequent diagnoses while on PrEP; and preference for continuing PrEP use and service delivery models including price, setting, and regimen. Variables were assessed using univariate analysis. Categorical variables were tested with the Chi squared test if the expected value in each cell was at least 5; otherwise, Fisher's exact test was used. Continuous variables were examined using the Mann-Whitney $U$ test. The STROBE guideline was implemented in reporting the study.

\section{Results}

Between September 2017 and May 2018, 292 MSM were assessed. ${ }^{12} \mathrm{~A}$ total of 71 (median age, 32 years) MSM were included in the study. Their demographic and behavioural profiles are shown in Table 1. Half of the participants were self-referred; the rest were referred from community-based organisations and collaborating HIV services. Thirty-three (46\%) participants reported a history of STIs, 15 of whom had a diagnosis in the preceding 6 months. All participants were PrEP-naïve, but 10 (14\%) had previously been put on post-exposure prophylaxis after high-risk sexual exposure. Engagement in chem-sex was reported by 25 (35\%) of the participants. The self-perceived risk of HIV infection was high in one-fifth of the participants. Over the 30-week prescription period, there was a total follow-up of 1639 person-weeks. At the end of the study period, 57 (80\%) participants remained in the programme. Fourteen withdrew from the study, nine of whom (64\%) did so within the initial 2 months. The following reasons for withdrawal were given by 10 participants: low or no perceived risk (6); adverse events (2); concern about adverse drug effects or drug interactions (1); unaffordability (1); inconvenience or too busy to attend the clinic (1); and on the advice of friends (1).
TABLE I. Demographic characteristics and behavioural profile of men who have sex with men who participated in the study $(n=7 I)^{*}$

\begin{tabular}{|c|c|}
\hline Demographics & \\
\hline Age (years) & $32(27-40)$ \\
\hline \multicolumn{2}{|l|}{ Ethnicity } \\
\hline Local Chinese & $63(89 \%)$ \\
\hline Mainland Chinese & $3(4 \%)$ \\
\hline Southeast Asian & $2(3 \%)$ \\
\hline Overseas non-Chinese & $3(4 \%)$ \\
\hline $\begin{array}{l}\text { Attainment of postsecondary level } \\
\text { education }\end{array}$ & $60(85 \%)$ \\
\hline \multicolumn{2}{|l|}{ Work status } \\
\hline Full-time employment & $52(73 \%)$ \\
\hline Self-employed & $4(6 \%)$ \\
\hline Part-time working or freelancer & $6(8 \%)$ \\
\hline Student & $5(7 \%)$ \\
\hline Unemployed & $4(6 \%)$ \\
\hline \multicolumn{2}{|l|}{ Monthly income (US\$1=HK\$7.8) } \\
\hline$<\mathrm{HK} \$ 15000$ & $14(20 \%)$ \\
\hline HK\$15 000-30000 & $27(38 \%)$ \\
\hline HK\$30 001-50 000 & $16(23 \%)$ \\
\hline$>\mathrm{HK} \$ 50000$ & $14(20 \%)$ \\
\hline \multicolumn{2}{|l|}{ Source of referral } \\
\hline Self-referred & $35(49 \%)$ \\
\hline Community-based organisations & $27(38 \%)$ \\
\hline Public HIV services & $9(13 \%)$ \\
\hline \multicolumn{2}{|l|}{ Health status } \\
\hline $\begin{array}{l}\text { History of sexually transmitted infection } \\
\text { diagnosis }\end{array}$ & $33(46 \%)$ \\
\hline Having chronic illnesses & 0 \\
\hline On long-term medications & $5(7 \%)$ \\
\hline $\begin{array}{l}\text { Age of first sexual intercourse with men } \\
\text { (years) }\end{array}$ & $20(18-22)$ \\
\hline \multicolumn{2}{|l|}{ Behavioural profile } \\
\hline \multicolumn{2}{|l|}{ Usual sexual role } \\
\hline Insertive & $21(30 \%)$ \\
\hline Versatile & $30(42 \%)$ \\
\hline Receptive & $20(28 \%)$ \\
\hline Ever on HIV post-exposure prophylaxis & $10(14 \%)$ \\
\hline \multicolumn{2}{|l|}{ Behavioural risk in the past 6 months } \\
\hline $\begin{array}{l}\text { Diagnosed with sexually transmitted } \\
\text { infections }\end{array}$ & $15(21 \%)$ \\
\hline Engaged in recreational drug use & $25(35 \%)$ \\
\hline Had more than one male partner & $63(89 \%)$ \\
\hline \multicolumn{2}{|l|}{ Perceived risk of HIV infection } \\
\hline High & $14(20 \%)$ \\
\hline Medium & $33(46 \%)$ \\
\hline Low & $24(34 \%)$ \\
\hline
\end{tabular}

Abbreviation: HIV = human immunodeficiency virus

* Data are shown as No (\%) or median (interquartile range) 
Full adherence to attending all visits was achieved by all participants who completed the study, though $16 \%(74 / 460)$ of the pre-arranged appointments required rescheduling. The rates of adherence to HIV testing (six time-points), plasma creatinine testing (three time-points), and STI screening (three time-points) were 100\%, 99.5\%, and $100 \%$, respectively. Adherence to daily use of TDF/FTC, as derived from the questionnaires administered at each visit, is shown in Table 2. Overall, 60 out of 69 (87\%) participants with diary data reported having ever omitted at least one dose. A median of two to three doses was missed between each pair of consultations, which took place at intervals of 4 to 8 weeks. The total number of doses omitted ranged from 1 to 71 (median, 6; interquartile range $=3-14$ ). Occasions of condomless sex without concurrent use of TDF/FTC were noted, which occurred in 20 out of 953 (2\%) person-days. While participants were advised to take the TDF/ FTC tablet at about the same time each day, some $14 \%$ to $25 \%$ reported not being able to stick to the strict 24-hour dosing interval.
Adverse events relating to the use of TDF/FTC were reported by 35 (52\%) out of the 67 participants who attended the clinic at least twice (Table $3^{13}$ ). The main adverse events were: dyspepsia (18\%), loose stool or increased bowel motions (16\%), fatigue $(15 \%)$, headache $(12 \%)$, and nausea with or without decreased appetite (12\%). Other adverse events included difficulty falling or staying asleep, dizziness, and anxiety or depression. These adverse events were generally mild (grade 1), self-limiting, and did not bother the participants, and the majority resolved within the first week. Two participants withdrew from the study because of grade 2 adverse events that lasted over 2 weeks. One complained of nausea, diarrhoea, stomach upset, and anxiety, which resolved 2 days after stopping TDF/FTC at week 8 . The other had headache shortly after initiation on PrEP and depressed mood and fleeting suicidal ideation in the ensuing 2 weeks, which resolved upon stopping at week 4 . Separately, plasma creatinine was measured at baseline, week 12, and week 28; there was a $>20 \%$ increase of plasma creatinine in $7 / 63$ (11\%) and 6/57 (11\%) of the participants compared

TABLE 2. Adherence of men who have sex with men to pre-exposure prophylaxis use*

\begin{tabular}{|c|c|c|c|c|}
\hline Markers for non-adherence & $\begin{array}{c}\text { Weeks 2-6 } \\
(n=64) \dagger\end{array}$ & $\begin{array}{c}\text { Weeks } 7-12 \\
(n=61)\end{array}$ & $\begin{array}{c}\text { Weeks 13-20 } \\
(n=58) \dagger\end{array}$ & $\begin{array}{c}\text { Weeks 21-28 } \\
\quad(n=57)\end{array}$ \\
\hline Ever forgotten to take PrEP & $24(38 \%)$ & $33(54 \%)$ & $36(62 \%)$ & $29(51 \%)$ \\
\hline Ever decided to skip PrEP & $4(6 \%)$ & $8(13 \%)$ & $7(12 \%)$ & $8(14 \%)$ \\
\hline Reported missed dose & $23(36 \%)$ & $34(56 \%)$ & $35(60 \%)$ & $31(54 \%)$ \\
\hline No. of missed doses & $2(1-4)$ & $3(2-5)$ & $3(2-5)$ & $3(2-5)$ \\
\hline Did not take PrEP tablet at the correct time & $13(20 \%)$ & $14(23 \%)$ & $8(14 \%)$ & $14(25 \%)$ \\
\hline Took more than one tablet per day & $5(8 \%)$ & $5(8 \%)$ & $4(7 \%)$ & $13(23 \%)$ \\
\hline
\end{tabular}

Abbreviation: PrEP = pre-exposure prophylaxis

* Data are shown as No. (\%) or median (interquartile range)

$\dagger$ Data missing for one participant

TABLE 3. Adverse events related to the use of pre-exposure prophylaxis $(n=67)^{*}$

\begin{tabular}{|c|c|c|c|c|c|}
\hline & \multicolumn{4}{|c|}{ Grade $^{13}$} & \multirow[t]{2}{*}{ Total } \\
\hline & 1 & 2 & 3 & 4 & \\
\hline \multicolumn{6}{|l|}{ General } \\
\hline Fatigue & $10(15 \%)$ & 0 & 0 & 0 & $10(15 \%)$ \\
\hline Dizziness & $4(6 \%)$ & 0 & 0 & 0 & $4(6 \%)$ \\
\hline \multicolumn{6}{|l|}{ Gastrointestinal } \\
\hline Loose stool or increased bowel motions & $11(16 \%)$ & 0 & 0 & 0 & $11(16 \%)$ \\
\hline Nausea with or without decreased appetite & $8(12 \%)$ & 0 & 0 & 0 & $8(12 \%)$ \\
\hline Dyspepsia & $12(18 \%)$ & 0 & 0 & 0 & $12(18 \%)$ \\
\hline \multicolumn{6}{|l|}{ Neurological } \\
\hline Headache & $8(12 \%)$ & 0 & 0 & 0 & $8(12 \%)$ \\
\hline Anxiety or depression & $2(3 \%)$ & $1(1.5 \%)$ & 0 & 0 & $3(4.5 \%)$ \\
\hline Difficulty falling or staying asleep & $5(7.5 \%)$ & $1(1.5 \%)$ & 0 & 0 & $6(9 \%)$ \\
\hline
\end{tabular}


with baseline, respectively. Three (5\%) participants who completed the study had a $20 \%$ increase in plasma creatinine readings at both weeks 12 and 28 . None had an estimated glomerular filtration rate level $<60 \mathrm{~mL} / \mathrm{min} / 1.73 \mathrm{~m}^{2}$ at any time in the course of receiving PrEP.

None of the participants contracted HIV in the course of the study. Condomless sex was reported by 70 out of 71 (99\%) of the participants. Their behavioural profiles and STI diagnoses at different time intervals are shown in Table 4 . Out of the 59 MSM followed up through week 20 or beyond, compared with baseline, condom use decreased in $22(49 \%)$, increased in $9(20 \%)$, and was unchanged in $14(31 \%)$ for sex with known partners $(n=45)$, and the corresponding rates for newly met partners $(n=47)$ were 19 (40\%), 7 (15\%), and 21 (45\%), respectively. Reduction of condom use with newly met partners was associated with the attainment of postsecondary education (odds ratio $[\mathrm{OR}]=2.00,95 \%$ confidence interval $[\mathrm{CI}]=1.46-2.75, \mathrm{P}=0.07$ by Fisher's exact test). There was no association between reduction of condom use and demographic characteristics, reasons for taking PrEP, or history of risk behaviours. The proportion of PrEP users engaging in chem-sex was similar before (41\%) and after PrEP (32\%-40\%).

With regard to STIs, 2 (3\%), 3 (4\%), and 16 (23\%) were positive for $N$ gonorrhoeae (NAAT), $C$ trachomatis (NAAT), and syphilis serology (nine treponemal only, seven treponemal and non- treponemal) at baseline, respectively. One of the 16 (6\%) syphilis serology-positive MSM was a newly diagnosed infection. Over a follow-up period of 1639 person-weeks among those retained in the study for at least 12 weeks, 13 incident STIs (one $N$ gonorrhoeae [incidence rate $=3.17$ per 100 personyears], three $C$ trachomatis [incidence rate $=9.52$ per 100 person-years], and nine syphilis [incidence rate $=28.55$ per 100 person-years]) had occurred. The participants with incident STI were more likely to be poppers users (46\% and $18 \%$ of participants with and without incident STIs used poppers, respectively; $\mathrm{OR}=3.81,95 \% \mathrm{CI}=1.03-14.10, \mathrm{P}=0.06)$. None of the participants had positive results for hepatitis $C$ virus antibody at baseline or follow-up.

At the last visit during the prescription period, participants $(n=65)$ were asked about their future intentions regarding PrEP. Fifty-eight (89\%) responded that they would like to continue with PrEP after the study. The MSM who preferred to continue PrEP after the study were more likely to be aged $\geq 28$ years $(\mathrm{OR}=6.03,95 \% \mathrm{CI}=1.06-34.17$, $\mathrm{P}=0.04$ ) [Table 5]. Peer influence was important, as none of those uninterested in continuing on had discussed PrEP use with their boyfriends $(\mathrm{P}=0.04)$ or sex partners $(\mathrm{P}=0.04)$. Price $(83 \%)$ was the most concerning factor affecting their PrEP-using decision, followed by efficacy (46\%) and potential adverse drug effects (42\%) [Table 6]. Some 14\% were worried about embarrassment or stigma related to

TABLE 4. Condomless anal sex and diagnoses of sexually transmitted infections at baseline and during the 28-week observation period*

\begin{tabular}{|c|c|c|c|c|c|}
\hline & $\begin{array}{c}12 \text { weeks } \\
\text { before PrEP } \\
(n=71)\end{array}$ & $\begin{array}{c}\text { Week 2-6 } \\
(n=65)\end{array}$ & $\begin{array}{c}\text { Week } 7-12 \\
(n=61)\end{array}$ & $\begin{array}{l}\text { Week 13-20 } \\
(n=59)\end{array}$ & $\begin{array}{c}\text { Week 21-28 } \\
(n=57)\end{array}$ \\
\hline \multicolumn{6}{|l|}{ No. of male sex partners } \\
\hline Total & $4(3-10)$ & $4(2-6)$ & $4(2-6)$ & $4(2-7)$ & $4(2-7)$ \\
\hline Newly acquainted & $2(1-5)$ & $2(1-4)$ & $2(1-4)$ & $2(0-5)$ & $2(1-5)$ \\
\hline Had receptive anal sex & $45(63 \%)$ & $45(69 \%)$ & $41(67 \%)$ & $36(61 \%)$ & $37(65 \%)$ \\
\hline Engagement in recreational drug use & $29(41 \%)$ & $21(32 \%)$ & $23(38 \%)$ & $23(39 \%)$ & $23(40 \%)$ \\
\hline \multicolumn{6}{|l|}{ Condomless sex all or most times } \\
\hline With newly acquainted partner & $15 / 64(23 \%)$ & $24 / 55(44 \%)$ & $29 / 58(50 \%)$ & $20 / 49(41 \%)$ & $28 / 51(55 \%)$ \\
\hline With known partners & $21 / 62(34 \%)$ & $28 / 57(49 \%)$ & $32 / 57(56 \%)$ & $27 / 52(52 \%)$ & $33 / 52(63 \%)$ \\
\hline Person-days of sex without PrEP & NA & 20 & 20 & 4 & 11 \\
\hline Self-reported STI symptoms & $7(10 \%)$ & $2(3 \%)$ & $3(5 \%)$ & $5(8 \%)$ & $6(11 \%)$ \\
\hline \multicolumn{6}{|l|}{ Incident bacterial STI† } \\
\hline Syphilis & $16(23 \%)$ & - & $3(5 \%)$ & - & $6(11 \%)$ \\
\hline Chlamydia & $3(4 \%)$ & - & $2(3 \%)$ & - & $1(2 \%)$ \\
\hline Gonorrhoea & $2(3 \%)$ & - & 0 & - & $1(2 \%)$ \\
\hline Person-episodes of STI & 21 & - & 5 & - & 8 \\
\hline
\end{tabular}

Abbreviations: IQR = interquartile range; NA = not applicable; PrEP = pre-exposure prophylaxis; STI = sexually transmitted infections

* Data are shown as No. (\%) or median (IQR), unless otherwise specified

$\dagger$ STI not screened at weeks 2, 6, and 20 
TABLE 5. Factors associated with preference for continuing PrEP after completion of study*

\begin{tabular}{|c|c|c|c|c|}
\hline & $\begin{array}{c}\text { Uninterested in } \\
\text { continuing PrEP } \\
\quad(n=7)\end{array}$ & $\begin{array}{c}\text { Interest in } \\
\text { continuing PrEP } \\
(n=58)\end{array}$ & OR (95\% Cl) & $\begin{array}{c}\text { P value (Fisher's } \\
\text { exact test) }\end{array}$ \\
\hline \multicolumn{5}{|l|}{ Demographics } \\
\hline Age $\geq 28$ years & $2(29 \%)$ & $41(71 \%)$ & $6.03(1.06-34.17)$ & 0.04 \\
\hline Local Chinese & $6(86 \%)$ & $52(90 \%)$ & $1.44(0.15-14.11)$ & 0.57 \\
\hline Attained postsecondary education & $6(86 \%)$ & $48(83 \%)$ & $0.80(0.09-7.40)$ & 1.00 \\
\hline Full-time or self-employed & $4(57 \%)$ & $47(81 \%)$ & $3.21(0.63-16.43)$ & 0.16 \\
\hline Monthly income $\geq \mathrm{HK} \$ 30000$ & $2(29 \%)$ & $24(41 \%)$ & $1.77(0.32-9.87)$ & 0.69 \\
\hline \multicolumn{5}{|l|}{ Six months before baseline } \\
\hline History of STI diagnosis & 0 & $14(24 \%)$ & - & 0.33 \\
\hline No HIV+ sex partners & $1(14 \%)$ & 17 (29\%) & $2.49(0.28-22.26)$ & 0.66 \\
\hline Engagement in recreational drug use & $1(14 \%)$ & $21(36 \%)$ & $3.41(0.38-30.24)$ & 0.41 \\
\hline Having $>1$ sex partner & $7(100 \%)$ & $50(86 \%)$ & - & 0.58 \\
\hline \multicolumn{5}{|l|}{ Risk profiles } \\
\hline Ever had sex with HIV+ partners & $2(29 \%)$ & $24(41 \%)$ & $1.77(0.32-9.87)$ & 0.69 \\
\hline Ever had sex with females & $2(29 \%)$ & $10(17 \%)$ & $0.52(0.09-3.08)$ & 0.60 \\
\hline Ever had group sex & $4(57 \%)$ & $47(81 \%)$ & $3.21(0.63-16.43)$ & 0.16 \\
\hline Engagement in sex while on recreational drugs & $1(14 \%)$ & $29(50 \%)$ & $6.00(0.68-53.01)$ & 0.11 \\
\hline High perceived HIV risk & $2(29 \%)$ & $11(19 \%)$ & $0.59(0.10-3.42)$ & 0.62 \\
\hline \multicolumn{5}{|l|}{ Reasons for joining PrEP study } \\
\hline Protection from HIV infection & $7(100 \%)$ & $54(93 \%)$ & - & 1.00 \\
\hline High anticipated HIV risk & $4(57 \%)$ & $25(43 \%)$ & $0.57(0.12-2.77)$ & 0.69 \\
\hline Desire to reduce/avoid condom use & $1(14 \%)$ & $19(33 \%)$ & $2.92(0.33-26.04)$ & 0.42 \\
\hline Sex partner being $\mathrm{HIV}+$ & 0 & $12(21 \%)$ & - & 0.33 \\
\hline Following others' recommendations & $2(29 \%)$ & $15(26 \%)$ & $0.87(0.15-4.98)$ & 1.00 \\
\hline \multicolumn{5}{|l|}{ Discussions about PrEP with } \\
\hline Friends & $7(100 \%)$ & $40(69 \%)$ & - & 0.18 \\
\hline Health workers other than doctors & 0 & $5(9 \%)$ & - & 1.00 \\
\hline Sex partners & 0 & $24(41 \%)$ & - & 0.04 \\
\hline Boyfriends & 0 & $23(40 \%)$ & - & 0.045 \\
\hline Family members & $1(14 \%)$ & $1(2 \%)$ & $0.11(0.006-1.91)$ & 0.21 \\
\hline \multicolumn{5}{|c|}{ Risk/behaviours while on PrEP as reported at the last visit } \\
\hline Completed the study & $2(29 \%)$ & 55 (95\%) & $45.83(6.14-342.01)$ & $<0.001$ \\
\hline Incident STI during study period & $1(14 \%)$ & $11(19 \%)$ & $1.40(0.15-12.88)$ & 1.00 \\
\hline Engagement in sex while on recreational drugs & $1(14 \%)$ & $22(38 \%)$ & $3.67(0.41-32.52)$ & 0.41 \\
\hline Sex partners also taking PrEP & $3(43 \%)$ & $20(35 \%)$ & $0.70(0.14-3.45)$ & 0.69 \\
\hline Always used condoms with new partners & $3 / 5(60 \%)$ & $11 / 52(21 \%)$ & $0.18(0.03-1.21)$ & 0.09 \\
\hline Always used condoms with known partners & $1 / 5(20 \%)$ & $14 / 52(27 \%)$ & $1.47(0.15-14.34)$ & 1.00 \\
\hline Used ecstasy & 0 & $13(22 \%)$ & - & 0.33 \\
\hline Used poppers & $1(14 \%)$ & $13(22 \%)$ & $1.73(0.19-15.72)$ & 1.00 \\
\hline \multicolumn{5}{|l|}{ PrEP preferences } \\
\hline Daily regimen & $5(71 \%)$ & $34(59 \%)$ & $0.57(0.10-3.17)$ & 0.69 \\
\hline On-demand regimen & $2(29 \%)$ & $29(50 \%)$ & $2.50(0.45-13.94)$ & 0.43 \\
\hline Time-driven PrEP & 0 & $17(29 \%)$ & - & 0.18 \\
\hline Injectable PrEP & $2(29 \%)$ & $16(28 \%)$ & $0.95(0.17-5.42)$ & 1.00 \\
\hline
\end{tabular}

Abbreviations: $95 \% \mathrm{Cl}=95 \%$ confidence interval; $\mathrm{HIV}=$ human immunodeficiency virus; $\mathrm{OR}=$ odds ratio; $\mathrm{PrEP}=$ pre-exposure prophylaxis; $\mathrm{STI}=$ sexually transmitted infection

* Data are shown as No. (\%), unless otherwise specified 
TABLE 6. Preference for PrEP delivery models $(n=65)$

\begin{tabular}{|c|c|}
\hline \multicolumn{2}{|l|}{ Preferred service characteristics } \\
\hline \multicolumn{2}{|l|}{ Price $(\mathrm{HK} \$)^{\star}$} \\
\hline Free & $13(20 \%)$ \\
\hline $1-500$ & $20(31 \%)$ \\
\hline 1000 & $24(37 \%)$ \\
\hline 2000 & $8(12 \%)$ \\
\hline \multicolumn{2}{|l|}{ Delivery setting $\dagger$} \\
\hline Current pilot clinic with university affiliation & $50(77 \%)$ \\
\hline $\begin{array}{l}\text { Department of Health HIV service } \\
\text { (Integrated Treatment Centre) }\end{array}$ & $17(26 \%)$ \\
\hline Community-based organisation & $43(66 \%)$ \\
\hline Another public hospital & $24(37 \%)$ \\
\hline Private clinic & $18(28 \%)$ \\
\hline Others & $2(3 \%)$ \\
\hline \multicolumn{2}{|l|}{ PrEP regimen† } \\
\hline Daily & $39(60 \%)$ \\
\hline On-demand & $31(48 \%)$ \\
\hline Time-driven & $17(26 \%)$ \\
\hline Injectable & $18(28 \%)$ \\
\hline \multicolumn{2}{|l|}{ Factors affecting PrEP using decision† } \\
\hline Efficacy & $30(46 \%)$ \\
\hline Price & $54(83 \%)$ \\
\hline Regimen & $10(15 \%)$ \\
\hline Adverse drug effects & $27(42 \%)$ \\
\hline Service organisation & $17(26 \%)$ \\
\hline Service location & $20(31 \%)$ \\
\hline Service time & $20(31 \%)$ \\
\hline Privacy & $20(31 \%)$ \\
\hline Embarrassment or stigma related to PrEP & $9(14 \%)$ \\
\hline
\end{tabular}

Abbreviations: HIV = human immunodeficiency virus; PrEP = pre-exposure prophylaxis

* Price: US $\$ 1=H K \$ 7.8$

† Multiple selections possible

PrEP. The majority, 63 of 68 (93\%), had disclosed their PrEP status to their partners, and 9 (14\%) of them reported ever experiencing stigma. Half (51\%) considered a monthly cost for PrEP of $\leq \mathrm{HK} \$ 500$ reasonable. Two-thirds (66\%) accepted communitybased organisations as the portal for receiving PrEP and monitoring. Over half $(60 \%)$ and about half (48\%) favoured daily mode and on-demand PrEP, respectively. Fewer than one-third favoured injection (28\%) and time-driven PrEP (26\%).

\section{Discussion}

Men who have sex with men have continued to be the hardest-hit population by the global HIV epidemic, ${ }^{14}$ and Hong Kong is no exception. While PrEP has not yet been implemented, its acceptance is generally high, at $78.6 \%$ among MSM in late $2016,{ }^{15}$ but only $1 \%$ have been reported to have accessed PrEP. ${ }^{16}$ Our study was the first that has piloted PrEP delivery to MSM in Hong Kong. Our results showed that the operation of a PrEP clinic in Hong Kong is feasible and acceptable to the MSM community, as evidenced by our high retention rate of $80 \%$ among users of a daily regimen over the 7 -month observation period. Severe adverse reactions were uncommon in our study, echoing the conclusion on the safety profile of PrEP, as illustrated in clinical studies and confirmed in reviews. ${ }^{4,17}$

None of the MSM in the study contracted HIV, but the small sample size did not allow the efficacy of PrEP to be evaluated. Elsewhere, a metaanalysis of multiple studies with different regimens concluded that PrEP reduced the HIV infection risk by $70 \%$ in the presence of high adherence. ${ }^{4}$ The failure of PrEP is very uncommon, as shown by a large-scale PROUD study ${ }^{2}$ and by evaluating real world data. ${ }^{18}$ In our pilot study, adherence to daily TDF/FTC, creatinine testing, and HIV/STI monitoring was high. Non-adherence to TDF/FTC could potentially lead to resistance if HIV infection occurs in the course of PrEP, though its incidence has remained low. ${ }^{19}$ Condomless sex in conjunction with the omission of TDF/FTC, which can be referred as PrEP-unprotected condomless sex, was relatively uncommon. Risk compensation, defined as the increased practice of condomless sex in PrEP users, is an emerging concern..$^{20,21}$ Our results did not confirm any consistent increase of risk compensation behaviours, an observation shared by other recent studies. ${ }^{4,22,23}$ Increased incidence of STI could be more prevalent in the initial period of PrEP introduction ${ }^{19,24}$ or restricted to a subpopulation of MSM regardless of PrEP use..$^{20}$ It is uncommon to see MSM starting to engage in condomless anal sex after PrEP initiation..$^{23}$ One modelling study showed that STI incidence would decline with increased PrEP coverage. ${ }^{25}$ With increasing PrEP coverage, non-PrEP users may become a neglected community when planning STI/HIV interventions. ${ }^{26}$

The present results highlight that the major obstacle to PrEP implementation is its cost, as patented TDF/FTC is too expensive for outof-pocket acquisition. ${ }^{16}$ In our study, requiring participants to pay an amount closer to the cost of generic products (HK\$750 or $<\mathrm{US} \$ 100$ per month) appealed to only a fraction of the MSM approached. About half of the eligible MSM did not join this project because of the high cost incurred. ${ }^{12}$ Making PrEP free or affordable should be an effective strategy for preventing HIV transmission through high-risk behaviours. Taking reference to the situation in the US, different models for PrEP could be considered, including services at STI clinics, community 
health centres, community-based organisations, pharmacies, and private primary care providers. ${ }^{10}$ This study highlighted issues for consideration in the establishment of a local PrEP service. The need for dispensing prescription medicine alongside HIV/STI testing and toxicity monitoring has made access to PrEP complex. Vertical programmes that have conventionally offered HIV testing to high-risk populations have been more prepared to implement PrEP than overburdened primary care services tend to be. ${ }^{27}$ Other innovative models of PrEP delivery have been reported in other countries, such as pharmacybased clinics in Seattle in the US, ${ }^{28}$ community health centres in Bangkok, Thailand, ${ }^{29}$ and integrated sexual reproductive health services in Wales. ${ }^{30}$ While those models provide lessons, they may not be relevant to the situation in Hong Kong. Finally, stigma could be a major deterrent to accessing PrEP, as expressed by some of the MSM who refused to participate. ${ }^{31}$ In rolling out PrEP, a marketing strategy that focuses on health protection rather than risk reduction may be more appropriate..$^{32} \mathrm{~A}$ non-targeting approach regarding behavioural risk could be less stigmatising and may still be cost-effective at achieving HIV prevention in low-HIV incidence settings. ${ }^{33}$

The current study has some limitations. First, the sample size was small, such that the results may not be generalisable to the situation of the entire MSM community in Hong Kong. Second, sampling bias could not be eliminated, as the study included selfreferred MSM and those referred from collaborating organisations. Individuals reluctant to participate in a clinical trial and those unwilling or unable to pay for TDF/FTC were excluded. Nevertheless, the study did manage to recruit MSM with high-risk behaviours, including those who engaged in chem-sex. Finally, we relied on self-reporting for tracking of HIV/STI risk, a strategy that might have underestimated highrisk behaviours. By subjecting the participants to STI screening at multiple time-points, we detected otherwise-hidden STIs both at baseline and during the course of PrEP. For maximum effectiveness, PrEP should go hand in hand with community-based STI/HIV monitoring, so that prompt treatment can be offered to those diagnosed with infections, while those testing negative can continue to be prescribed TDF/FTC for HIV prevention.

\section{Conclusion}

While cost is a major obstacle to scaling up implementation of PrEP, making it available free may pose an added challenge to countries or cities where a policy decision to introduce PrEP as a public health service has yet to be made. Our results suggested that a partially self-financed mode of delivery is feasible and could appeal to a proportion of risk-taking MSM. Fee-based PrEP provision has been available in other Asian Pacific countries like
Thailand. $^{34}$ A partially self-financed model could be an interim measure, and this is less demanding of resources in locations where generic TDF/FTC is not available (as in Hong Kong). Operationally, PrEP cannot be implemented in isolation but must be provided in conjunction with periodic HIV/STI testing, as reflected in our study. Provision of PrEP serves the dual purpose of HIV prevention and opportunistic STI screening, which enables prompt treatment to be given so as to reduce reinfections and the infection burden in the MSM community. Rectal $C$ trachomatis or $N$ gonorrhoeae infection has been shown to be associated with an increased risk of HIV transmission ${ }^{35}$ and should therefore be considered as part and parcel of the HIV prevention package. Finally, as PrEP is a biomedical form of HIV prevention, our results confirm that severe adverse events are uncommon, but moderate but intolerable reactions may occur in a small proportion of people on TDF/FTC, who would require clinical advice on cessation.

\section{Author contributions}

All authors had full access to the data, contributed to the study, approved the final version for publication, and take responsibility for its accuracy and integrity.

Concept or design: SS Lee, TH Kwan, TTN Lam.

Acquisition of data: TH Kwan, NS Wong, SS Lee, GCY Lui, DPC Chan, KCK Lee.

Analysis or interpretation of data: TH Kwan, NS Wong, SS Lee.

Drafting of the article: SS Lee.

Critical revision for important intellectual content: SS Lee, GCY Lui.

\section{Acknowledgement}

Ms Mandy Li, Mr Chengqian Ye, Mr Choi-yin Lam, and Dr See-long Lee are thanked for their assistance in participant enrolment and management of the research clinic. We thank AIDS Concern, CHOICE (Community Health Organisation for Intervention, Care and Empowerment), Boys' \& Girls' Clubs Association of Hong Kong, Integrated Treatment Centre, HIV services of Queen Elizabeth Hospital, Princess Margaret Hospital, and Prince of Wales Hospital for technical support and the referral of potentially eligible participants to the study. The Li Ka Shing Institute of Health Sciences and Stanley Ho Centre for Emerging Infectious Diseases of The Chinese University of Hong Kong are acknowledged for providing technical support in developing the analyses. Gilead Sciences, Inc. is acknowledged for drug donation in support of part of the study.

\section{Declaration}

The research data have been presented in part as posters at the Lancet-CAMS Health Summit 2018 (27-28 October 2018, Beijing, PR China), the 3rd Asia Pacific AIDS \& Co-infections Conference 2018 (28-30 June 2018, Hong Kong), HIV Glasgow 2018 (28-31 October 2018, Glasgow, United Kingdom), and the 10th IAS Conference on HIV Science 2019 (21-24 July 2019, Mexico City, Mexico). 


\section{Conflicts of interest}

GCY Lui has served as advisory committee member for Gilead Sciences, Merck, Sanofi Pasteur, and ViiV; and as a speaker for Gilead Sciences and Merck; and has received research grants/donations from Gilead Sciences, Merck and GSK. SS Lee has served as advisory committee member for Gilead Sciences, GSK and Merck; and as a speaker for Gilead Sciences sponsored events; and has received funding from Gilead Grants for community education activities.

\section{Funding/support}

This research was supported by the Council for the AIDS Trust Fund (Ref MSS264R), Hong Kong SAR Government.

\section{Ethics approval}

The study was approved by The Joint Chinese University of Hong Kong-New Territories East Cluster Clinical Research Ethics Committee (Ref CREC 2016.470) and registered at the Centre for Clinical Research and Biostatistics Clinical Trials Registry of The Chinese University of Hong Kong (Ref CUHK_CCRB00533). A Clinical Trials Certificate was obtained following application to Department of Health of the Hong Kong SAR Government (Ref 100860).

\section{References}

1. Grant RM, Lama JR, Anderson PL, et al. Preexposure chemoprophylaxis for HIV prevention in men who have sex with men. N Engl J Med 2010;363:2587-99.

2. McCormack S, Dunn DT, Desai M, et al. Pre-exposure prophylaxis to prevent the acquisition of HIV-1 infection (PROUD): effectiveness results from the pilot phase of a pragmatic open-label randomised trial. Lancet 2016;387:53-60.

3. Molina JM, Charreau I, Spire B, et al. Efficacy, safety, and effect on sexual behaviour of on-demand pre-exposure prophylaxis for HIV in men who have sex with men: an observational cohort study. Lancet HIV 2017;4:e402-10.

4. Fonner VA, Dalglish SL, Kennedy CE, et al. Effectiveness and safety of oral HIV preexposure prophylaxis for all populations. AIDS 2016;30:1973-83.

5. Nichols BE, Boucher CA, van der Valk M, Rijnders BJ, van de Vijver DA. Cost-effectiveness analysis of pre-exposure prophylaxis for HIV-1 prevention in the Netherlands: a mathematical modelling study. Lancet Infect Dis 2016;16:1423-29.

6. Department of HIV/AIDS, World Health Organization Consolidated guidelines on HIV prevention, diagnosis, treatment and care for key populations. Switzerland: WHO Press; 2016. Available from: http://www.who.int/hiv/pub/ arv/arv-2016/en/. Accessed 28 Jan 2019.

7. Centers for Disease Control and Prevention, US Government. Preexposure prophylaxis for the prevention of HIV infection in the US-2017: a clinical practice guideline. Available from: https://www.cdc.gov/hiv/pdf/ risk/prep/cdc-hiv-prep-guidelines-2017.pdf. Accessed 3 Sep 2019.

8. European AIDS Clinical Society. EACS Guidelines 8.0. Available from: http://www.eacsociety.org/files/ guidelines_8.0-english-revised_20160610.pdf. Accessed 28 Jan 2019.

9. To KW, Lee SS. HIV pre-exposure prophylaxis in South East Asia: a focused review on present situation. Int J Infect
Dis 2018;77:113-7.

10. Mayer KH, Chan PA, Patel R, Flash CA, Krakower DS. Evolving models and ongoing challenges for HIV preexposure prophylaxis implementation in the United States. J Acquir Immune Defic Syndr 2018;77:119-27.

11. Lee SS, Petersen EP. Overcoming 'purview paradox' to make way for the effective implementation of PrEP in preventing HIV transmission. Int J Infect Dis 2018;77:1056.

12. Kwan TH, Wong NS, Lui GC, Lee KC, Lee SS. Acceptability of an incentivised PrEP programme for men who have sex with men at high risk of HIV infection in Hong Kong: an implementation study. Lancet 2018;392 Suppl 1:S77.

13. US Department of Health and Human Services. Division of AIDS (DAIDS) Table for grading the severity of adult and paediatric adverse events. Version 2.0, November 2014. Available from: https://rsc.niaid.nih.gov/sites/default/files/ daids-ae-grading-table-v2-nov2014.pdf. Accessed 28 Jan 2019.

14. Beyrer C, Sullivan P, Sanchez J, et al. The increase in global HIV epidemics in MSM. AIDS 2013;27:2665-78.

15. Kwan TH, Lee SS. Predictors of HIV testing and their influence on PrEP acceptance in men who have sex with men: a cross-sectional study. AIDS Behav 2018;22:1150-7.

16. Wang Z, Lau JT, Fang Y, Ip M, Gross DL. Prevalence of actual uptake and willingness to use pre-exposure prophylaxis to prevent HIV acquisition among men who have sex with men in Hong Kong, China. PLoS One 2018;13:e0191671.

17. Trang TP, Dong BJ, Kojima N, Klausner JD. Drug safety evaluation of oral tenofovir disoproxil fumarateemtricitabine for pre-exposure prophylaxis for human immunodeficiency virus infection. Expert Opin Drug Saf 2016;15:1287-94.

18. Marcus JL, Hurley LB, Nguyen DP, Silverberg MJ, Volk JE. Redefining human immunodeficiency virus (HIV) preexposure prophylaxis failures. Clin Infect Dis 2017;65:1768-9.

19. Gibas KM, van den Berg P, Powell VE, Krakower DS. Drug resistance during HIV pre-exposure prophylaxis. Drugs 2019;79:609-19.

20. Nguyen VK, Greenwald ZR, Trottier H, et al. Incidence of sexually transmitted infections before and after preexposure prophylaxis for HIV. AIDS 2018;32:523-30.

21. Beymer MR, DeVost MA, Weiss RE, et al. Does HIV preexposure prophylaxis use lead to a higher incidence of sexually transmitted infections? A case-crossover study of men who have sex with men in Los Angeles, California. Sex Transm Infect 2018;94:457-62.

22. Milam J, Jain S, Dubé MP, et al. Sexual risk compensation in a pre-exposure prophylaxis demonstration study among individuals at risk of HIV. J Acquir Immune Defic Syndr 2019;80:e9-e13.

23. Grov C, Whitfield TH, Rendina HJ, Ventuneac A, Parsons JT. Willingness to take PrEP and potential for risk compensation among highly sexually active gay and bisexual men. AIDS Behav 2015;19:2234-44.

24. Hoornenborg E, Coyer L, van Laarhoven A, et al. Change in sexual risk behaviour after six months of pre-exposure prophylaxis use: results from the Amsterdam pre-exposure prophylaxis demonstration project. AIDS 2018;32:152732.

25. Jenness SM, Weiss KM, Goodreau SM, et al. Incidence 
of gonorrhea and chlamydia following human immunodeficiency virus preexposure prophylaxis among men who have sex with men: a modeling study. Clin Infect Dis 2017;65:712-8.

26. Phanuphak N, Phanuphak P. Time to focus more on condomless anal sex in non-PrEP users. Lancet HIV 2018;5:e410-1.

27. Venter WD. Pre-exposure prophylaxis: the delivery challenge. Front Public Health 2018;6:188.

28. Tung EL, Thomas A, Eichner A, Shalit P. Implementation of a community pharmacy-based pre-exposure prophylaxis service: a novel model for pre-exposure prophylaxis care. Sex Health 2018;15:556-61.

29. Phanuphak N, Sungsing T, Jantarapakde J, et al. Princess PrEP program: the first key population-led model to deliver pre-exposure prophylaxis to key populations by key populations in Thailand. Sex Health 2018;15:542-55.

30. Knapper C, Birley H, Couzens Z, Jones AT, Parker I. How to do it: setting up a PrEP service in an integrated sexual reproductive health service setting. Sex Transm Infect
2018;94:327-30.

31. Calabrese SK, Tekeste M, Mayer KH, et al. Considering stigma in the provision of HIV pre-exposure prophylaxis: reflections from current prescribers. AIDS Patient Care STDS 2019;33:79-88.

32. Rivet Amico K, Bekker LG. Global PrEP roll-out: recommendations for programmatic success. Lancet HIV 2019;6:e137-40.

33. Wong NS, Kwan TH, Tsang OT, et al. Pre-exposure prophylaxis (PrEP) for MSM in low HIV incidence places: should high risk individuals be targeted? Sci Rep 2018;8:11641.

34. Zablotska I, Grulich AE, Phanuphak N, et al. PrEP implementation in the Asia-Pacific region: opportunities, implementation and barriers. J Int AIDS Soc 2016;19(Suppl 6):21119.

35. Bernstein KT, Marcus JL, Nieri G, Philip SS, Klausner JD. Rectal gonorrhea and chlamydia reinfection is associated with increased risk of HIV seroconversion. J Acquir Immune Defic Syndr 2010;53:537-43. 